\title{
Correntes e contracorrentes da memória e do sublime em dois contos da bacia amazônica
}

\author{
Corrientes y contracorrientes de la memoria y de lo sublime en dos cuentos de la \\ cuenca amazónica \\ Iran de SOUZA* \\ Universidade Federal do Pará (UFPA) \\ Tânia SARMENTO-PANTOJA* \\ Universidade Federal do Pará (UFPA)
}

\begin{abstract}
RESUMO: Este trabalho tem como objetivo observar os percursos da memória e as representações do sublime nos contos La llocllada e Poraquê, dos escritores Francisco Izquierdo Ríos (2010) e João Meirelles Filho (2017), o primeiro ambientado na Amazônia peruana e o segundo na Amazônia brasileira. As hipóteses que nos guiam são a de que a fulguração da memória como elemento narrativo em ambos os contos decorre de um mesmo estímulo externo - a sublevação das águas da Bacia Hidrográfica Amazônica provocada por fenômenos naturais que estabelecem marcos na vida dos personagens - , e de que o sublime emerge como efeito estético associado ao ato da recordação dos narradores de forma diferenciada nos dois textos ficcionais. Para as considerações sobre a operação narrativa prenunciadora da memória tomaremos como referenciais as contribuições de Paul Ricoeur (2007), Maurice Halbwachs (1990), Pierre Nora (1993), Jacques Le Goff (1990), Paolo Rossi (2010) e Aleida Assmann (2011). Já as discussões sobre o sublime terão como referência os conceitos formulados por Dionísio Longino (2015) e Edmund Burke (2016).
\end{abstract}

PALAVRAS-CHAVE: Memória, Sublime, Rio Amazonas, Francisco Izquierdo Ríos, João Meirelles Filho.

RESUMEN: Este artículo tiene como objetivo observar los caminos de la memoria y las representaciones de lo sublime en las historias La llocllada y Poraquê, de los escritores Francisco Izquierdo Ríos y João Meirelles Filho, el primero tiene como escenario la Amazonía peruana, mientras que el segundo la Amazonía brasileña. Como hipótesis tenemos, que el destello de la memoria, como elemento narrativo en ambos cuentos, proviene del mismo estímulo externo, como la agitación de las aguas de la cuenca del Amazonas causada por fenómenos naturales que marcan hitos en la vida de los personajes y esa sublimidad emerge como un efecto estético asociado con el acto de recordar de los narradores de manera diferente en los dos textos de ficción. Para las

\footnotetext{
* Iran de Souza (Irisvaldo Laurindo de Souza). Mestrando em Estudos Literários pela UFPA.

BolsistaCapes. E-mail: irandesouza@gmail.com

* Doutora em Estudos Literários. Professora do Curso de Letras (FALE/ILC), do Programa de Pósgraduação em Letras da UFPA e do Programa de Pós-graduação Linguagens e Saberes naAmazônia. Bolsista Produtividade em Pesquisa (CNPq). E-mail: t.sarmentopantoja@gmail.com
} 
consideraciones sobre la operación narrativa de la memoria nos referiremos a las contribuciones de Paul Ricoeur (2007), Maurice Halbwachs (1990), Pierre Nora (1993), Jacques Le Goff (1990), Paolo Rossi (2010) y Aleida Assmann (2011). Las discusiones sobre lo sublime se referirán a los conceptos formulados por Dionísio Longino (2015) y Edmund Burke (2016).

PALABRAS CLAVE: Memoria, Sublime, río Amazonas, Francisco Izquierdo Ríos, João Meirelles Filho.

\section{INTRODUÇÃO}

Um arco geográfico abarca este trabalho de ponta a ponta. Parte do sopé da Cordilheira dos Andes no Peru, onde nasce o Rio Amazonas, e avança por quase 7.000 quilômetros a leste até a ilha de Marajó, no Brasil, onde o monumental curso d'água encontra o Oceano Atlântico. Tal arco não se estende porém no espaço físico e sim no território da ficção. A cartografia válida, aqui, é a da literatura.

No ponto mais ocidental da rota que traçamos, isto é, nas nascentes andinas do rio-mar, ambienta-se o nosso primeiro objeto de análise, o conto de ficção La llocllada, do autor peruano Francisco Izquierdo Ríos. No outro extremo, a leste, já no estuáriodelta do grande caudal, está ambientado o conto Poraquê, do escritor brasileiro João Meirelles Filho. Apesar das diferenças de tempo, longitude, estilo, dicção e expressão linguístico-literária, é possível estabelecer aproximações entre ambos.

Em primeiro lugar, La Locllada e Poraquê inserem-se num seleto, diríamos melhor, num diminuto corpus ficcional que tem como leitmotiv um conjunto de fenômenos naturais singulares que acontecem na Bacia Hidrográfica Amazônica, dentre os quais a maré oceânica conhecida como pororoca, as enchentes, os deslizamentos de morros e encostas que fazem transbordar os leitos dos rios, e ainda as "terras caídas" nas ribanceiras dos grandes caudais; em segundo, narram o drama e a tragédia do morador da região em face destes levantes violentos e destruidores das águas; em terceiro, tanto num como noutro conto verifica-se a incidência, em maior ou menor grau, de intercursos da memória e do sublime em suas operações narrativas. Memória e sublime. Reflitamos um pouco sobre esses dois conceitos. 


\section{A contracorrente da memória no rio do esquecimento}

Para Paolo Rossi (2010), a memória é o que nos viabiliza e legitima no tempo. Sem ela não teríamos biografia, recordações, narrativa própria nem como indivíduos nem enquanto coletividade. Sequer teríamos identidade, cuja marca primordial, nas sociedades históricas em que vivemos, é justamente a da temporalidade. Fundida não apenas à identidade, mas também à consciência, a memória é um fenômeno condicionado pela experiência; seu usufruto demanda razão, vontade e esforço, sem os quais o esquecimento - larápio da experiência — pode prevalecer sobre ela.

A dialética entre memória e esquecimento está no cerne deste trabalho. E se o elemento que tanto em La llocllada como em Poraquê fustiga ambos é a fúria destruidora das águas, ousamos, em busca de um gradiente, transpor as ribanceiras do Amazonas, as fronteiras do tempo e do espaço, da história e do mito, e saltar para as do Lethe, onde, como sugerem Platão e Aristóteles, a recordação (anamñesis) configura já um ato empreendido voluntariosamente contra a corrente do esquecimento. Sim, "é a contracorrente do Lethe que a anamnésia opera", corrobora Paul Ricoeur (2007, p. 46), e é enfrentando-a, opondo-se a ela, que a memória progride e prevalece.

Uma das operações mais significativas da memória, e a de maior interesse para este trabalho, é a operação narrativa, aquela que Pierre Jeunet, como anota Jacques Le Goff (1990), chama de ato mnemônico fundamental. E para que possa empreender este ato tanto nos campos da oralidade como da escrita, na história como na literatura, a memória percorre um longo caminho desde as próprias origens. Maurice Halbwachs (1990) anota que são três as suas instâncias: a individual, a coletiva e a histórica. A primeira remonta à infância e, em processo evolutivo, emerge como ponto de vista da memória coletiva, abrindo-se para o outro pela necessidade de pertencimento que todos temos em relação a alguém (na relação amorosa), a algum grupo específico de interesse (no âmbito da vida social), a alguma comunidade difusa (no plano maior da nacionalidade, por exemplo). Por isso recordar é um ato impregnado de pertencimento - ou, por oposição, da falta dele.

Halbwachs diferencia porém memória coletiva e memória histórica. Assevera que uma não se confunde com a outra. Mas tanto ele como Pierre Nora (1993) advogam 
que a memória, aquilo que já não se pode viver novamente, precisa de estímulos. Dito de outro modo, demanda reinvenção permanente para que possa durar, transmitindo-se entre as gerações. E neste esforço de duração — já que não há memória espontânea —, nesta navegação na contracorrente do Lethe, requer cartografias próprias que se estabelecem por meio dos chamados lugares de memória. E para tê-los "é preciso criar arquivos, [...] é preciso manter aniversários, organizar celebrações”, diz Nora (1993, p. 13), bem como é necessário escrever prosa e verso, pintar quadros e fazer registros fotográficos, produzir filmes e compor canções, inscrevendo-os, entre a funcionalidade de uns e o simbolismo de outros, como pontos luminosos dos mapas da memória humana.

Aledia Assman (2011), por sua vez, faz diferença entre lugares de memória e memória dos locais. Enquanto os primeiros são móveis, isto é, podem ser transferidos no espaço, a segunda é fixa, irremovível em relação ao seu posicionamento original. Para a autora alemã, esses locais fixos podem ser geracionais, na medida em que o vínculo com eles se faz a partir de cadeias de parentesco entre vivos e mortos; memorativos, nos quais a vinculação se assenta sobre narrativas resgatadas e legadas a coetâneos e pósteros; podem ser de recordação, quando o interesse histórico predomina; e ainda podem ser traumáticos, palco de feridas como o Holocausto, para as quais não há cura.

Rossi (2010) também nos ajuda a ampliar o arco teórico das reflexões sobre a psicologia da memória. Lembra que Freud acreditava que todo indivíduo herda marcas mnésicas das gerações que o precederam; ou seja, traços inscritos em seu sistema psíquico em registro primevo, puro e ainda desprovido de emoções. E, à parte as divergências que separaram Freud e Jung, acrescenta o historiador italiano, o segundo também colocou as marcas mnésicas no centro de seus estudos e reflexões sobre a memória. Todavia, para Jung, a pré-história da espécie prevalece sobre a do indivíduo. Assim, “ao passo que o inconsciente individual é preenchido por 'imagens vividas', o inconsciente coletivo é preenchido por formas 'que o indivíduo não viveu pessoalmente"” (JUNG apud ROSSI, 2010, p. 152).

Perguntamo-nos se é possível relacionar a teoria do inconsciente coletivo de Jung e suas imagens arquetípicas aos elementos da estética do sublime que haveremos de observar principalmente em La llocllada. Enquanto "formas de pensamento 
primitivas e arcaicas" (JUNG apud ROSSI, 2010, p. 153) essas imagens fortes provocam espanto e horror no ouvinte ou leitor e só podem ser expressas pelo narrador em tom maior, isto é, em modulação elevada. Ora, neste caso estamos no registro do sublime estabelecido por Dionísio Longino [séc. I d.C.] (2015) ainda no início da era cristã, segundo o qual este efeito decorre da grandeza, ou seja, daquilo que é capaz de provocar assombro e terror.

Quase dois milênios depois de Longino, Edmund Burke [1729-1797] diferenciou o sublime e o belo, separando-os em territórios distintos ainda que comunicantes. Em sua tipologia, o sublime foi inserido no campo do medo. "Medo da perda total do eu, da morte, do inconcebível”, aponta Seligmann-Silva (2000, p. 83). Na perspectiva do filósofo e orador irlandês, se o fundamento da beleza é o prazer, o princípio do sublime é a dor, e seu efeito, em mais alto grau, é o assombro, que ele define como um "estado de alma em que todos os seus movimentos estão suspensos e com algum grau de horror" (BURKE, 2016, p. 65). Portanto, se a beleza é a experiência do prazer e da serenidade, o sublime é fundamentalmente a experiência do estupor e do terror; experiência que também se pode ter, anota Burke ainda que de passagem, diante dos elementos terríficos da natureza; diante, por exemplo, da vastidão de terras e águas, já que "a grandeza da dimensão é uma causa poderosa do sublime” (Ibid., p. 78).

\section{Um conto da amazônia andina: La llocllada}

O escritor Francisco Izquierdo Ríos nasceu em 1910, em Saposoa, na província de Huallaga, no Peru. Morreu em Lima, em 1981. Foi contista, poeta, ensaísta, educador e funcionário público. Publicou mais de 20 livros. Originário da Amazônia peruana, retratou a vida ribeirinha e o ambiente da floresta em escritos de teor regional, em prosa e verso, nos quais tomou como fonte o imaginário mítico e as tradições populares. Também destacou-se como autor infantojuvenil e pesquisador de folclore.

Em 2010, em comemoração ao centenário de nascimento de Ríos, a Universidad de San Marcos, por meio da Facultad de Letras y Ciencias Humanas, em Lima, reeditou sua obra completa. O primeiro tomo foi dedicado aos contos e poemas do autor. Selva y otros cuentos, publicado originalmente em 1949, inclui La llocllada. Observemos que o substantivo llocllada sequer tem sinônimo em espanhol. Deriva da língua pré- 
colombiana quéchua, ainda falada por 10 milhões de pessoas na América do Sul, em cujo vocabulário também figura grafada com $\mathrm{K}$ - lloklla -, estritamente relacionada a aguaceiros, inundações e transbordamentos de cursos fluviais. ${ }^{3}$ Indica excesso, "loucura" e desordem na natureza. Nomeia, assim, um fenômeno típico da Amazônia andina: o desmoronamento de colinas nas encostas e picos da cordilheira, com o depósito de sedimentos terrosos nos leitos dos rios, principalmente lama e lodo. O escritor Carlos Tafur Ruíz [1939] (2013), que tomou a expressão como título de um de seus livros, aprofunda a explicação:

La llocllada, como se chama em Alto Mayo, es un fenómeno natural que se produce de tiempo en tiempo, cuando las aguas del río, estando bastante crecidas, por accíon de un derrumbe se vuelven lodosas, motivando que gran parte de su fauna ictiológica perezca por asfixia, lo qual es aprovechado por los pobladores ribereños. (RUIZ, 2013, p. 37). ${ }^{4}$

O relato ficcional de Ruíz tem sabor de lenda. Sugere que a mortandade de peixes em tempo de lloklla costuma ser momento de agrura por um lado mas de fartura, por outro, ao operar o "milagre" da multiplicação dos pescados para os ribeirinhos pobres da região de San Martín, na Amazônia peruana. Já no conto de Ríos observamos uma situação diferente. Seu relato gira em torno de uma lloklla sem fartura entre os pobladores. O que aconteceu foi uma tragédia, uma desgraça sem precedentes. Porque "Juasus, hom, nunca lloclló el río como esa vez algunos viejecitos cuando se referían a la tremenda 'llocllada' del río, que espantó a las gentes de la ciudad de Saposoa, hace setenta años más o menos" (RÍOS, 2010, p. 101). ${ }^{5}$

Observemos que já na abertura do conto Ríos recorta temporalmente a narrativa. E prestemos atenção ao narrador. O tempo do discurso dele é o presente, porém o fato que se propõe a contar — o tempo da história — remonta a um passado distante em sete décadas ou mais. Foi um acontecimento tão extraordinário quanto trágico: numa manhã

\footnotetext{
${ }^{3}$ O Vocabvlario de la Lengua Qquichua, do jesuíta Diego Gonçalez Holguín [1560-1620], publicado em 1608, registra o termo lloclla com variantes: llocllay, loclla para, llocllaypacha, llocllani o llocllamuni, llocllarccon, llocllarcarin, puccay lloccla, lloklla ou llokllay. Consultamos uma reedição de 1952, como consta nas Referências.

4 “A llocllada, como é chamada no Alto Rio Mayo, é um fenômeno natural que acontece de tempos em tempos, quando as águas do rio, já muito cheias, ficam lodosas por causa de desmoronamentos, o que faz com os peixes morram por asfixia e sejam aproveitados pelos ribeirinhos das aldeias." [tradução livre]

5 "Jesus, homi, o rio nunca lloclló como daquela vez que alguns velhinhos recordam como a maior llocllada que já houve, e que aterrorizou o povo da cidade de Saposoa há mais ou menos uns setenta anos." [tradução livre]
} 
aprazível, os moradores da bela e florida Saposoa, na província de Huallaga, levaram um grande susto: as águas do Rio Saposoa, a oeste da cidade, bem como as do riacho Serrano, que a recortam, estavam rubras como sangue. E logo ouviu-se um estrondo.

¡Era la llocllada!... El río había inundado todas sus riberas, llegando hasta a lamer las paredes de algunas casas de la población; el paisaje era desolador... Platanales, algodonales, cañaverales estaban totalmente anegados, así como los grandes árboles emergían apenas de las aguas barrosas. (RÍOS, 2010, p. $101)^{6}$

A sub-bacia do Rio Huallaga (um dos formadores do Maranõn, que flui para o Ucayali, que já é o Amazonas em curso inicial) transbordara. Avolumados ao máximo, o mediano Saposoa e o modesto Serrano inundaram ruas, estradas e plantações. O segundo escalou até mesmo os tabuleiros das pontes no sítio urbano, deixando adultos sem trabalhar, crianças sem ir à escola, a rotina suspensa pela fúria das águas rebeladas, embora não estivesse chovendo e o sol brilhasse no firmamento.

Como a discursar para uma plateia, o narrador tece a cadeia dos fatos. Fora o mais assombroso dos dias, ele diz: a enchente passara da média, o rio subia sem parar. A correnteza arrastava, afogados, animais pequenos e grandes. Quadrúpedes, aves e víboras escapavam dos bosques e invadiam a cidade. No céu, papagaios, garças e patos selvagens, apavorados, migravam para outras paragens. Os peixes, pobrecitos, engolfados pelo barro, mortos aos milhares. Nas choças ribeirinhas levadas pelo turbilhão das águas, cadáveres de homens, mulheres e crianças que, surpreendidos pela enxurrada, não puderam salvar-se. Um dia diluviano e de muitos terrores no qual até um monstro foi visto em Saposoa.

\begin{abstract}
En uno de esos momentos, hasta dicen que pasó un animal raro, semiasfixiado por el barro de las aguas, que nunca habían visto ni conocido las gentes, y que, como cuentan ellas, era algo así como un elefante, con una trompa larga y el cuerpo "murco-murco", es decir, con una serie de granulaciones, y de color verduzco, que bajaba moviendo la trompa de un lado para otro, como tratando de no ingerir más agua barrosa. Un monstruo cuyo aspecto y presencia llenó de más pánico a la gente que, asustada, contemplaba la llocllada. (RÍOS, 2010, p. 103). ${ }^{7}$
\end{abstract}

\footnotetext{
${ }^{6}$ Era a llocllada!... O rio havia inundado todas as suas ribeiras, chegando até a lamber as paredes de algumas casas dos moradores; a paisagem era desoladora... Bananais, algodoais, canaviais estavam totalmente inundados, assim como as grandes árvores entre as águas barrentas. [tradução livre]

7 “Em um desses momentos, dizem até que apareceu um animal raro, quase asfixiado pelo barro das águas, um animal que nunca ninguém havia visto nem conhecido, e que, como contam as pessoas, era
} 
Após descrever os acontecimentos funestos daquele dia o narrador dá uma explicação lógica para eles: a montante, nos ramais da Cordilheira dos Andes, sucedera-se la llocllada. O deslizamento de morros para os leitos dos rios fora descomunal. Além dos prejuízos materiais e clamores causados - as chácaras ribeirinhas devastadas, homens e animais mortos, a fome e a doença a grassar, las viejecitas horrorizadas e chorosas pelo que viram como um duro castigo divino - , a catástrofe natural escreveu uma página dolorosa na história de Saposoa; página que o narrador, com voz memorial e modulada em terceira pessoa, transmite à sua audiência.

Como não entrever em La llocllada o narrador oral de que fala Benjamin em seu ensaio antológico, o contador de histórias em vias de extinção numa modernidade que aderiu à escrita e a outros suportes de memória? Quem está ali senão ele, em presença e espírito, olhos nos olhos dentre os seus? Que outra senão a sua é esta voz experiente, voz que sabe dar conselhos, inclusive o de não esquecer o passado sob risco de perder a identidade individual e grupal? Sim, aí está ele, em pleno ato voluntário de recordação, a narrar para terceiros fatos evocados no diapasão da "reminiscência [que] funda a cadeia da tradição, que transmite os acontecimentos de geração em geração" (BENJAMIN, 2012, p. 228). Inferimos que este registro de memória, o da reminiscência, filtro de sensações, é o que prevalece em La llocllada.

Como já está anotado, a voz responsável pela operação narrativa no conto de Ríos é, decerto, a expressão de uma memória plural, coletiva, embora necessariamente consignada a uma memória individual, nos termos de Halbwachs (1990), Nora (1993) e Ricoeur (2007). Em seu instante evocativo, os fatos narrados por ele não dizem respeito a este ou aquele indivíduo - sequer há personagens nomeados na história -, mas a toda Saposoa, que emerge coletivamente como protagonista do conto. Ademais, o narrador nem fala de acontecimentos vistos com

algo assim como um elefante, tinha uma tromba larga e o corpo murco-murco, assim dizendo, todo granulado, e de cor esverdeada, que movia a tromba de um lado para outra na tentativa de não engolir mais água barrenta. Um monstro cujo aspecto e aparição levou mais pânico ainda às pessoas que, assustadas, contemplavam a llocllada." [tradução livre] 
seus próprios olhos e sim pelos olhos dos anciãos da cidade - algunos viejecitos -, prestando um testemunho já de segunda ou terceira geração.

Atentemos ainda ao fato de que o local onde esta memória se cristaliza, se fixa e encontra a máxima nitidez é o rio transbordante. Força eidética, dominante, o curso d'água convulsivo rebaixa o entorno além de suas ribanceiras a uma fotografia fora de foco. Ele é o palco principal do drama e da tragédia narrados. E assim o Saposoa/Serrano, lugar sobre o qual se organizam as imagens fortes da llocllada amazônico-andina, fulgura, ainda que pelo efêmero instante da narração, não como o rio do esquecimento mas como o próprio rio da lembrança e, enquanto tal, como lugar de memória, segundo o conceito de Nora (1993).

Refinemos um pouco mais a última afirmação, ajustando-a ao conceitual de Assmann (2011). Pois o fato é que da forma como sobressai no conto o rio transbordante figura, decerto, menos como um lugar de memória e mais como um local memorativo.

\footnotetext{
Locais memorativos são aqueles onde se cumpriam atos admiráveis ou em que o sofrimento assumiu caráter exemplar. Registros feitos com sangue - como perseguição, humilhação, derrota e morte - têm um valor de destaque na memória mítica, nacional e histórica. Eles são inesquecíveis, na medida em que são traduzidos por um grupo em recordação positivamente vinculadora. (ASSMANN, 2011, p. 348-349). [Grifos nossos]
}

Observando os grifos que fizemos na passagem, chequemos a pertinência das formulações da autora para o contexto de La llocllada: sim, os fatos narrados no conto, e que tiveram o rio como palco, são admiráveis, no sentido de que foram extraordinários; envolvem sofrimento, pois suas consequências foram ominosas; seu registro é o da subjugação (imposta pela natureza em fúria), sangue e morte (de homens e animais); acrescente-se ainda que tais fatos se inserem na memória mítica, porque longínqua e enevoada pelo tempo, e histórica, porque empírica e testemunhada, da comunidade de Saposoa; fatos esses inesquecíveis (passados adiante de geração em geração como agora faz o narrador), e que se traduzem como recordação positivamente vinculadora, ou, na perspectiva de Halbwachs, configuram uma memória coletiva impregnada de pertencimento.

Para dar fecho, agora, à análise do conto de Ríos, reflitamos um pouco sobre a sua modulação do ponto de vista do sublime. O narrador, que se expressa em terceira 
pessoa como já anotamos, evoca o gran pánico de décadas antes ainda sobressaltado e em tom de espanto, logo com a passionalidade e a excitação recomendadas por Longino (2015) aos oradores de seu tempo. Atentemos para as semelhanças entre o orador da polis antiga e o narrador pré-moderno como o de La llocllada; são evidentes, embora as diferenças também o sejam; e correlacionemos os dois, aqui, como vozes da experiência no âmbito de suas comunidades.

Apliquemos, pois, as prescrições de Longino ao narrador da selva peruana, e observemos se ele as atende. Em suas elocuções, o que ele busca é provocar impacto ao nível da psyche, impressionar, suspender por um instante a razão e açambarcar a todos os ouvintes - e quiçá a nós, leitores — num mesmo sentimento de angústia e torpor? Sim. Seu discurso é construído sobre megalegorias que o tornam grandioso e pomposo? Decerto. Ele mantém o tom o elevado ao longo de toda a sua fala, fazendo com que suas partes se integrem organicamente e com alto teor expressivo? Exatamente. Os sintagmas de seu vocabulário são enrijecidos por termos fortes e as imagens que ele constrói para o ouvinte/leitor são primordialmente hiperbólicas? A resposta é novamente sim.

Apenas a título de exemplo de algumas dessas características, observamos a ocorrência em profusão ao longo das três páginas do conto de palavras e expressões que tendem ao excesso. Dentre elas, tremenda, terrible, cataclismo, desolador, inmenso ruído, asombroso fenómeno fluvial, espectáculo grandioso y terrorífico, extraño animal, gigantescas boas, formidable llocllada, atmósfera de pestilência. ${ }^{8}$ Mas nem somente por causa de registros imagéticos, semânticos e tropológicos a este modo, que é o de Longino, enquadramos La llocllada no registro do sublime.

Os termos de Burke (2016) complementam a argumentação. Inferimos por meio deles que aquilo que o narrador também pretende oferecer à sua plateia de ouvintes/leitores é a experiência do medo, da dor e, por extensão, do terror, que vem a ser o princípio governante do sublime. Uma experiência amarga que, em suas palavras reminiscentes, estendeu-se inclusive além do dia em que o rio transbordou. "Luego, muchas enfermedades asolaron a la ciudad, y decían también que, después de la

8 Tremenda, terrível, cataclismo, desolador, ruído imenso, assombroso fenômeno fluvial, espetáculo grandioso e terrível, animal estranho, jiboias gigantescas, formidável deslizamento, atmosfera de pestilência. [tradução livre]

Revista Moara, n. 53, ago-dez 2019 ISSN: 0104-0944 Recebido em 12/11/2019

Avaliado em 29/11/2019 
llocllada, los bosques cercanos a ella se poblaron de boas, serpientes que antes no existían en ellos..." (RÍOS, 2010, p. 104). ${ }^{9}$

Saposoa, uma cidade assolada pela doença e pelo perigo. Uma população assombrada e aterrorizada pela ameaça de aniquilação. Um lugar à sombra da dor e da morte - a rainha dos terrores, sempre à espreita dos viventes. “(...) un paisaje de infinita desolación..." (RÍOS, 2010, p. 103). ${ }^{10}$ Note-se que este, em síntese, é o registro do sublime para Burke. E é dentro de seus quadrantes estéticos que o narrador memorialista de La Llocllada levanta a voz e tange o próprio relato.

Mas ainda não daremos, a esta altura de nossas considerações, a análise do conto de Ríos por encerrada. Há ainda um veio que precisamos explorar a partir das "deixas" proporcionadas por Longino e Burke, e elas dizem respeito ao hiperbolismo prolífico das imagens construídas pelo narrador. A mais forte e sem dúvida a mais sublime de todas é a do animal monstruoso como um elefante, com tromba larga e corpanzil granulado e verdoengo, o qual, oriundo ninguém sabe de onde, era arrastado pela correnteza, e mexia a tromba para um lado e outro com o intuito de não engolir mais água barrenta do que já houvera engolido, evitando engolfar-se, debatendo-se contra a morte.

Ora, donde este animal horrendo, esta "imagem do mundo sem tempo, de certo modo eterna, contraposta à momentânea imagem do mundo de nossa consciência"? (JUNG apud ROSSI, 2010, p. 152). Donde este monstro capaz de romper o pretérito perfeito da lembrança, correr pelo infinitivo da recordação e emergir no presente do indicativo da evocação? De que labirintos da memória plural das gentes de Saposoa ele vem à tona, agora, pela voz singular do narrador? Virá do "depósito da experiência atávica de muitos milhões de anos, [...] eco da pré-história, ao qual cada século agrega uma pequeníssima contribuição de variações e diferenciações”? (Ibid., p. 152). Inferimos com Jung, evidentemente, que o bicho verdoengo e estrambótico arrastado correnteza abaixo fulgura como representação do inconsciente coletivo em La llocllada, recortando a narrativa para além do real e do histórico, e inscrevendo-a nos círculos difusos e intangíveis do fantástico e do imemorial.

\footnotetext{
9 "Logo, muitas doenças assolaram a cidade, e diziam também que, depois da grande llocllada, os bosques dos seus arredores foram tomados por jiboias, serpentes que até então não eram vistas por ali ..." [tradução livre]

10 “[...] uma paisagem de infinita desolação...” [tradução livre]
} 


\section{UM CONTO DA FOZ DO AMAZONAS: PORAQUÊE}

Avancemos, agora, rumo ao outro ponto extremo do arco geográfico-ficcional que abrimos neste trabalho. Sigamos em sentido leste, e alcancemos a foz do Rio Amazonas. É lá, precisamente na ilha de Marajó, como dissemos, que está ambientado Poraquê, de autoria do escritor brasileiro João Meirelles Filho, conto que complementa o corpus em análise. Meirelles Filho nasceu em São Paulo (SP), em 1960. Vive em Belém (PA) desde 2004. É empreendedor social e escritor. Grande conhecedor do chamado Brasil profundo - o Brasil além da costa atlântica, adentrado nos sertões publicou 17 obras até o ano de 2019, a maioria com foco na história e na diversidade socioambiental da hinterlândia brasileira, incluindo o Livro de Ouro da Amazônia. $O$ Abridor de Letras, sua primeira experiência com prosa de ficção, foi laureado com o Prêmio Sesc de Literatura em 2017, na categoria contos.

Como já dissemos, Poraquê tem como cenário uma fazenda da ilha de Marajó, no estuário-delta do Rio Amazonas. O personagem principal, que vem a ser o próprio narrador, é o proprietário da terra. Ouvimo-lo, no geral, a falar na primeira pessoa do singular, mas às vezes também na primeira do plural, via de regra no pretérito do indicativo. O tempo do seu relato está circunscrito, portanto, ao passado - uma narrativa de todo memorial e monofônica em que tão somente o seu ponto de vista recorta o espaço narrado. Já o tempo de seu discurso parece próximo aos fatos rememorados, porém não dispomos de maiores informações a respeito. Meirelles Filho delineia-o progressivamente no curso dos acontecimentos sem ao menos nomeá-lo.

Ao iniciar a leitura de $O$ abridor de letras, adentramos nós mesmos, de imediato, o mundo e o tempo pretéritos do narrador-personagem de Poraquê. Na casagrande, ele folheava, absorto, uma velha revista editada no início do século XX. Era uma publicação ilustrada que falava dos bichos, das plantas, das curiosidades da ilha, da novidade da hora - a chegada de búfalos importados — dos nomes científicos de bichos esquisitos como a piramboia, Lepidosiren paradoxa, que "na seca se enfurna nas poças dos terroados [...]. Até que as águas espoquem tudo. As águas. As águas grandes, as verdadeiras. As que vêm de cima e de lado, de baixo e de dentro" (MEIRELLES FILHO, 2017, p. 11). 
Observamos que o narrador-personagem adormeceu deitado em sua rede, na modorra do verão equatorial, entre imagens palustres e pensamentos encharcados. Ao reabrir os olhos, despertou com maus augúrios. Uma pergunta aflitiva o atordoava: qual o tamanho da próxima cheia? Que a enchente vinha todos os anos, mancomunada com as chuvas, invadindo a planície marajoara, terras baixas e alagadiças, ele sabia que vinha. De sua fazenda costeira, já dava para ver "a maré sempre tufando..." (Ibid. p. 11). Aliás, de lá dava para ver muita coisa das quais os próprios olhos duvidavam. Naquele momento, por exemplo, ele enxergava um ponto escuro e balouçante no rio-mar. Seria uma baleia encalhada? Seria uma nesga de terra largada ao sabor das correntes flúviomarinhas? Seria “um peixe-cobra gigante, aquele tinhoso, tão falado?” (Ibid., p. 13).

A calha do Rio Amazonas e o seu estuário-delta sempre foram lugares de fenômenos inenarráveis. E se lá em seu cosmo o narrador-personagem de Poraquê tinha ciência disso, nós, aqui do nosso observatório de leitura, também temos obrigação de saber. Devemos observar, por exemplo, que não bastasse o descomunal volume d'água do rio, a força da corrente é tal durante as enchentes que provoca deslocamentos de ribeiras e ribanceiras, à moda dos lloclladas andinos; são as chamadas terras caídas, que, largadas ao sabor de correntes e contracorrentes, transformam-se em torrões, baixios e coroas flutuantes.

No estuário-delta, um fenômeno ainda mais assombroso - porque destruidor da fauna e da flora e ameaçador das gentes - costuma ocorrer. Os primeiros moradores da região, os índios, o nomearam como pororoca. Trata-se do encontro ruidoso e violento entre a maré alta do oceano e os caudais amazônicos avolumados pelas enchentes. Conhecedor destas vontades da natureza, o narrador-personagem de Poraquê sabia, portanto, o que poderia vir pela frente: uma assolação, uma varredura provocada por águas revoltas. Sua agonia, crescente, acompanhava a própria escalada da maré. Primeiramente, o ponto escuro e balouçante no rio-mar revelava-se tão grande, mas tão grande, e cada vez mais próximo e visível, que logo fora chamado de Coroa Grande. Era uma ilha, de fato, uma terra caída e flutuante que se movera até estacionar, como de propósito, à ilharga da fazenda; e que "tanto ficava mais alta como se esparralhava" (MEIRELLES FILHO, 2017, p. 14); e que num átimo começara a ser ocupada por gente vinda ninguém sabe de onde; e que o menino Carlinhos, filho de seu encarregado, com a livre imaginação que sói ocorrer às crianças, logo chamou de "meu país"; e que, ausente 
dos mapas de navegação, poderia até complicar o trabalho dos práticos, impondo-lhes, por desaviso, o encalhe de suas embarcações.

Além da inquietude provocada pela Coroa Grande, a atmosfera começara a ficar encharcada demais. "Chovia todos os dias, por longas horas. [...] O tempo era assim nesta parte do ano. Os rios extravasados, as terras desaparecidas, num tudo-água por onde quer que se olhasse" (Ibid., 13). Na tábua de marés, augúrios cada vez piores: "Sizígia esta noite" (Ibid., p. 17). E, quanto mais água caindo do céu e se avolumando no rio-mar, maior a certeza: era ela que estava a caminho - a pororoca.

[...] a maré vazava. Com força impressionante, rugia, ríspida e rugosa. No horizonte, as ondas gigantescas que o mofento gosta, pororoca pra ficar em casa, no seco, e no alto. Dona Menina vaticinou: as espumas estão lacrimejando, o mar tá comendo as ondas. [...] Durante a noite, a maré crescida veio tufando, derrubando o curral, o quarto de arreio, espantando o que encontrou de criação no rumo do mato ou pra dentro da casa. (MEIRELLES FILHO, 2017, p. 23-28).

Sublevado, o rio-mar subia a cada dia inundando a fazenda braça por braça. Um apocalipse amazônico: a água tintada de tabatinga; búfalos rodopiando até a morte na correnteza; os cavalos agoniados com os cascos molhados; os bois evadidos do pasto em busca de terras altas; as piramboias, bichos tanto mal-ajambrados como arredios, boiando já debaixo da casa, "[...] juntas, alvoroçadas. Subindo a varanda. Pareciam ter medo da água, do barro" (Ibid., p. 28).

A enchente era tão grande, descomunal, que logo o narrador-personagem e seus empregados compreenderam que aquelas terras, as terras que haviam sido palco de sua existência até então, nunca mais voltariam à superfície, jamais seriam visíveis e habitáveis novamente. Afogar-se-iam para sempre. Derruir-se-iam no embate titânico entre o rio e o oceano. "Bocas de sertão amazônico", nelas cumprir-se-ia o vaticínio que jamais se cumprira no semiárido nordestino: o sertão viraria mar. E, se o futuro delineado seria esse, tudo o que restava ao seu proprietário e aos que o rodeavam era deixar para trás estas terras engolfadas por águas grandes, partindo em busca de um porto seguro. Arrumadas as tralhas na canoa-mãe, foi o que eles fizeram. E no momento da partida, conta o narrador-personagem, "embaixo da varanda da casa amontoavam-se os cavalos e os bezerros, sem ter pra onde ir. Em silêncio olhavam-nos, os olhos molhados. Os poraquês! Nunca os vira assim. Desesperados” (Ibid., p. 29). 
Busquemos em Poraquê as suas correntes e contracorrentes de memória. Afinal este trabalho parte da hipótese de que elas existem e constituem elementos importantes de sua operação narrativa. As que interessam aqui, evidentemente, são aquelas anteriores ao próprio tempo narrado - esse já no pretérito do indicativo - , e que constituem, por assim dizer, uma espécie de pretérito do pretérito. Com esta intenção, vamos seguir o narrador-personagem em seus atos, falas, pensamentos e interações com outros personagens e elementos circundantes. De volta ao "prólogo" do conto, é importante observar a revista que o fazendeiro marajoara folheava deitado em sua rede. Pertencera ao avô, ele suspeitava, embora o pai de seu pai (ou de sua mãe?) não tivesse espírito de colecionador; e remontava, talvez, ao "tempo do suíço" — à época de Emílio Goeldi [1859-1917] decerto, o zoólogo e naturalista cujo trabalho marcou época na região amazônica e no País, na virada do século XIX para o XX.

Nesta passagem inicial do conto, revelam-se para nós duas correntes paralelas de memória. A primeira, de ordem pessoal, relativa à própria genealogia do narradorpersonagem. Em seu ato memorativo, a evocação do avô o leva de volta à infância, tempo fabuloso, mas também formativo da personalidade e da memória como observaram, cada qual com seu corte epistemológico, Freud (apud ROSSI, 2010) e Halbwachs (1990). Porém notemos que esta memória individual figura, em Poraquê, com notória orientação de grupo, no caso o grupo familiar, constituindo-se, com profundo sentido de pertencimento, em memória coletiva.

Inferimos que outra corrente que perpassa o prólogo do conto de Meirelles Filho é aquela assinalada como memória científica. Pois o fato inegável é que o esquecimento também ronda a ciência. "Todo pesquisador e praticante de ciências sabe muito bem que não apenas grande parte de seu trabalho será esquecido (como acontece com a maior parte das coisas humanas)", lembra Rossi (2010, p. 183-184), como seus escritos logo serão relegados aos subterrâneos das bibliotecas. Mas em Poraquê, no instante em que folheava a publicação especializada de um século atrás, o narrador-personagem, por meio do seu ato voluntário de recordação, revivescia parte do saber científico acumulado - ainda que defasado — sobre a Amazônia e particularmente sobre o arquipélago marajoara. E tanto na primeira corrente de lembranças do "prólogo", a familiar, como na segunda, a científica, o que opera o pequeno milagre da memória, para utilizar a expressão de Paul Ricoeur (2007) ao nosso modo, é um simples objeto - 
uma revista; publicação que, ao cumprir este papel, deixa de ser um mero produto gráfico, ressignifica-se como arquivo, e constitui-se, dentro da noção estabelecida por Nora (1993), como lugar de memória.

Tirando agora o nosso foco deste elemento específico - a revista descerrando-o para outro de natureza ampla, no caso a própria fazenda, inferimos que a propriedade rural também se constitui, dentro da operação narrativa de Poraquê, em local geracional de memória, aquele que nos termos de Assmann (2011) vincula atávica e espacialmente os vivos e os mortos. Ouçamos, a propósito, a voz da consciência do próprio narrador-personagem enquanto ele observava a Coroa Grande cada vez mais próxima da propriedade que herdara de sua família:

\footnotetext{
Aqui nesta manga da fazenda velha, desta tapera centenária. Do curral do meu tataravô. Duzentos anos na família! Já nasci sabendo. Tudo isso era nosso. Tudo. Nosso. Os açaizeiros. O capinzal grande, as lagoas. E também as marés. Nossas. Os trapiches. As piramboias, tudo que é qualidade de garça, o gado, os acaris, os tamuatás, as peremas. Nossos. As famílias trabalhadoras. Tudo gente nossa. Gerações e gerações aqui. Compadres. Afilhados, afilhadas, madrinhas, padrinhos, gente nossa que a gente leva para criar na cidade! No nosso eito. [...] Este o sentimento, o mais sincero. Isto. Isto mesmo, sim, senhor, tudo isto me incomoda muito. (MEIRELLES FILHO, 2017, p. 20).
}

Do nosso ponto de vista, esta memória patriarcal eivada de sentimento de propriedade do narrador-personagem é constitutiva de sua própria identidade como sujeito. Ele é o dono da fazenda e, como tal, tece o fio de suas lembranças. Porém tanto uma, a memória, como outra, a identidade, estão fustigadas e ameaçadas, ali mesmo onde foram forjadas, por um elemento externo que ameaça aniquilá-las - a potência destruidora das águas que avançam irreversivelmente sobre as terras baixas e alagadiças da Amazônia Oriental. Se estas águas engolfarem tudo por ali, o que será dele, de seu patrimônio, de suas reminiscências de infância e juventude, de sua existência, enfim, no arco do tempo que vai do passado ao futuro?

A memória coletiva do clã de fazendeiros do narrador-personagem e dos grupamentos familiares dos próprios trabalhadores que o serviam registrava, geração após geração, traumas provocados pela fúria das águas que, ciclicamente encapeladas, impunham prejuízos a todos, sem distinção de classe. Então ele se perguntava: seria pior agora? "Até onde iria este desmazelo? Seria a falência? Desta vez não iríamos nos recuperar. Na história da família já houvera tanto caso de perda, mas, desta monta, acho 
que nunca surtira, pensava, profundamente envergonhado" (Ibid., p. 25). Sim, ele sabia as respostas para as próprias perguntas, e elas eram desalentadoras. O desastre se aproximava. Nem a benzedeira, dona Lilica, evitaria o pior com os poderes dos seus raminhos de arruda. Era chegado o momento extremo e peremptório em que "terra vira água. Água vira terra” (Ibid., p. 26).

Forçado a deixar tudo o que era seu para trás, o narrador-personagem evadiu-se da fazenda. E ao fazê-lo mal teve o que salvar das águas. Levou pouca coisa consigo à guisa de signo de sua própria história e de álibi para um dia — quem sabe? — desafogar sua memória das profundezas do rio-mar: “[...] um reio que ganhara quando menino, um capacete da Guerra de Vinte-e-quatro, o facão cabeça de cachorro, o embornal [...], o oratório da Mãe-menina" (Ibid., p. 28). Ao observar esta passagem, uma das últimas de Poraquê, inferimos que nela, e também nas demais fulgurações memorativas no prólogo e no desenvolvimento do conto, o registro em que a memória se dá não é propriamente o da reminiscência. Isto porque revivescer o que foi visto ou vivido no passado não é o ímpeto que faz o narrador-personagem entregar-se ao ato da recordação, e sim o desejo de ressignificar para o presente, decerto para o futuro, as próprias lembranças e os elementos de evocação que o ajudarão a refazer a narrativa de sua vida após o desastre das águas. Para este fim, arguimos, o que lhe será útil doravante será menos o que a memória o faz reviver e mais a sua dimensão cognitiva, o seu caráter de saber, o seu sentido de experiência, como sugere Ricoeur (2007).

Do ponto de vista do sublime, inferimos que o registro de elementos imagéticos, semânticos e tropológicos que causam este efeito é de moderado a baixo em Poraquê. Nos termos de Longino (2015), os sintagmas do texto ficcional de Meirelles Filho sequer são hipertrofiados e raivosos. Conduzido por seu narrador-personagem, o conto denota, no geral, uma modulação discursiva mais baixa (tapeinoteron), isto é, passa ao largo do tom exacerbado e grandiloquente característico das manifestações do sublime (hypsos).

Outra nota importante neste sentido, e ainda de acordo com a orientação conceitual de Longino, é que Meirelles Filho, ao investir numa narrativa mais realista e mais próxima das vivências do cotidiano do homem amazônico, dotou-a primordialmente de ethos, distendendo-a no que diz respeito às emoções, diluindo-a por vezes ao ponto do relaxamento psíquico dos personagens - o jogo de futebol na Coroa 
Grande num dia de domingo é emblemático neste sentido - , desbastando-a o suficiente para enfraquecer-lhe o pathos, isto é, a sua vocação para a tragédia.

Ao longo do conto, as suas imagens, inclusive as mais graves e tensas, revelam pouco hiperbolismo, mesmo as que oferecem mais possibilidades neste sentido. Um exemplo disso é a passagem do afogamento dos búfalos. À guisa de livrar os olhos do menino Carlinhos de contemplar a morte de matrizes que ele sabe chamar pelo nome - Malhadinha, Fazendeira, Rajada, Tudinha, Mansinha —, tentativa parcialmente fracassada aliás, autor e narrador-personagem evitaram tensionar os signos de assombro e terror que a situação oferecia: "Eu o tomei nos braços [o menino]. Levei-o para dentro. Fechei as persianas de madeira, as tramelas da porta, como isso se isso fosse apagar a imagem que ia em nossas mentes. Acalentei-o até que dormisse, e voltei pra varanda" (MEIRELLES FILHO, 2017, p. 24). Assim o menino Carlinhos foi protegido ao máximo da experiência lancinante da sublimidade e, por extensão, também nós, os leitores.

Acrescentemos, porém, uma última nota a respeito do sublime em Poraquê: eivado de certo sentido escatológico, apocalíptico, este conto da foz do Amazonas denota, em seus elementos psicológicos, medo, tensão e receio de aniquilamento dos homens e das coisas pelas grandes águas. Embora em segundo plano no conjunto da narrativa, isto naturalmente nos remete à concepção de sublime em Burke (2016), para quem tudo aquilo que excite as ideias de dor e de perigo, e desague em terror, é causa do sublime. No mais, no ponto de encontro tumultuoso entre o rio e o mar onde a história se desenrola, a ordem de todas as coisas é a grandeza, e "a grandeza da dimensão é uma causa poderosa do sublime” (BURKE, 2016, p. 78).

\section{CONCLUSÃO}

Apesar da convergência temática que fomentou o seu estudo em conjunto, os dois textos ficcionais analisados neste artigo denotam notórias diferenças de tempo, longitude, estilo, dicção e expressão linguístico-literária.

No que diz respeito ao narrador, observamos que em La llocllada ele é prémoderno, com notória performance de oralidade, com dicção pedagógica que emana sabedoria e experiência, uma voz que se faz ouvir entre narratários ocultos. Já em 
Poraquê o narrador revela-se de todo moderno, atomizado e desencantado - leia-se romanesco - , e embora não haja sugestões metatextuais em seu relato inferimos que, se houver um narratário a ouvi-lo em sua solidão, este há de ser tão somente o leitor diante da página escrita.

O narrador de La llocllada fala sempre em terceira pessoa - nunca autorreferente, jamais cabotino. O sujeito único de sua narrativa, como dissemos ao analisar o conto, é a própria cidade de Saposoa, um sujeito coletivo, portanto. Em Poraquê, o que temos é um homem a relatar fatos autorreferenciados, logo a expressarse em primeira pessoa, ainda que eventualmente, para melhor recortar os acontecimentos deletérios que conformam a sua narrativa, na qual há terceiros, ele seja obrigado a variar para a terceira.

Em La llocllada, a voz do narrador ecoa do presente para o pretérito. A plataforma temporal de sua enunciação, o tempo de seu discurso, como dissemos, é a atualidade. O tempo da história, o passado. E se o sabemos é porque numa única passagem de seu relato, a abertura, ele estabelece o agora como ponto de partida do arco que estende para trás: “[...] hace setenta años más o menos" "11 (RÍOS, 2010, p. 101). O narrador-personagem de Poraquê, esse opera sempre no passado. Não há ângulo presente para a projeção de sua narrativa memorial, o que explica também não haver sequer anúncio de futuro. Ele está, por assim dizer, circunscrito a um "tempo morto pela fúria das águas", anterioridade da qual só consegue abstrair-se se for para olhar ainda mais para trás - para o pretérito do pretérito, como foi dito - , ao empreender suas mais profundas operações de memória.

Aliás, essas operações, em La llocllada, se levarmos em conta as formulações principalmente de Ricoeur (2007), fulguram num intermezzo entre a memória coletiva e a histórica, já que a segunda erige-se a partir da primeira. Pois a tragédia narrada no conto andino, em sua tessitura memorialista, não apenas vincula os grupos sociais a um passado comum, mas ao fazê-lo produz a narrativa histórica que unifica todos eles numa comunidade maior; e o fio que cerze ambas as operações, juntando-as, é o do pertencimento. Em Poraquê, o narrador-personagem é portador de uma memória que fulgura no relato, primeira e necessariamente, sob o signo de sua própria individualidade. Da revista científica que ele folheia à fazenda que ainda lhe pertence

\footnotetext{
11 “[...] mais ou menos setenta anos atrás”. [tradução livre]
} 
enquanto narra, tudo em volta constitui signo identitário para ele, tudo se relaciona à sua biografia; mas como nunca estamos nem jamais estivemos sozinhos em nossa experiência da temporalidade, como preconiza Halbwachs (1990), sua memória estabelece conexões com o outro, a começar pela própria família, construindo-se e emergindo em necessária interação com diferentes sujeitos, ou seja, assumindo contornos coletivos, pluralizando-se.

Se em La llocllada, como vimos, o rio emerge como palco principal dos fatos lembrados, constituindo-se como local memorativo na concepção de memória dos locais preconizada por Assmann (2011), em Poraquê a fazenda é que se eleva, por sua vez, como local geracional de memória, por servir, sem possibilidade de deslocamento para outro lugar no espaço, a tantas gerações de proprietários e empregados.

Quanto à corrente do sublime, como vimos, o conto da sub-bacia do Huallaga sustenta o próprio discurso em tom maior, com pathos elevado, enquanto o da foz do Amazonas, ao investir no ethos, mantém-se em tom menor. E, por fim, a ocorrência de marcas mnésicas em ambos os contos, nos termos de Jung e Freud compilados por Rossi (2010), indicam que sua figuração mais forte e evidente em La llocllada assume os contornos arquetípicos do inconsciente coletivo, enquanto em Poraquê sua gramática é a das lembranças formadoras da infância.

Estas as conclusões a que chegamos, em meio a correntes e contracorrentes da memória e do sublime, na travessia que empreendemos entre as nascentes e a foz do riomar seguindo a rota de La llocllada e Poraquê, dois contos da Bacia Amazônica.

\section{REFERÊNCIAS}

ASSMANN, A. Espaços da Recordação: formas e transformações da memória cultural. Trad. Paulo Soethe. Campinas: Unicamp, 2011. 456 p.

BENJAMIN, Walter. Magia e técnica, arte e política. Obras escolhidas. Trad. Sergio Paulo Rouanet. São Paulo: Brasiliense, 2012. 271 p.

BURKE, Edmund. Investigação filosófica sobre as nossas ideias do Sublime e da

Beleza. Trad. Daniel Moreira Miranda. 1. ed. São Paulo: Edipro, 2016. 159 p.

HALBWACHS, Maurice. A memória coletiva. Trad. Laurent Léon Schaftter. São Paulo: Vértice, 1990. 190 p. 
HOLGUÍN, Diego Gonçález. Vocabvlario de la Lengua General de todo el Perv llamada Lengua Qquichua, o del Inca. Lima: Universidad Nacional Mayor de San Marcos, 1952.

LE GOFF, Jacques. História e memória. Trad. Bernardo Leitão [et al.]. Campinas: Editora da Unicamp, 1990. 553 p.

LONGINO, Dionísio. Do Sublime. Trad. Marta Isabel de Oliveira Várzeas. Coimbra; São Paulo: Imprensa da Universidade de Coimbra; Annablume, 2015. 113 p.

MEIRELLES FILHO, João. O abridor de letras. Rio de Janeiro: Record, 2017. 143 p.

NORA, Pierre. Entre memória e história: a problemática dos lugares. Trad. Yara Aun Khoury. Projeto História. São Paulo, dez. 1993. In: Les lieux de mémoire. I La

République, Paris, Gallimard, 1984. pp. XVIII-XLII.

RICOEUR, Paul. A memória, a história, o esquecimento. Trad. Alain François [et al.] Campinas, SP: Editora da Unicamp, 2007. 535 p.

RÍOS, Francisco Izquierdo. Cuentos. Obra completa. Tomo I. Lima: Fondo Editorial de la Universidad Nacional Mayor de San Marcos, 2010. 666 p.

ROSSI, Paolo. O passado, a memória, o esquecimento: seis ensaios da história das ideias. Trad. Nilson Moulin. São Paulo: Editora Unesp, 2010. 240 p.

RUÍZ, Carlos Tafur. La llocllada: relatos. Lima: Trazos, 2013. 67 p.

SELIGMANN-SILVA, Márcio. A história como trauma. In.: NESTROVSKI, Arthur; (orgs.). Catástrofe e representação: ensaios. São Paulo: Escuta, 2000. 264 p. 